\title{
直列接続リアクトル回路を用いた周波数三倍器における 周期倍加分岐とカオスアトラクタ
}

\author{
正員酢 谷㙇 磨 (金沢工大) \\ 正貝別所一夫 (金沢工大)
}

A Period-Doubling Bifurcation and a Chaotic Attractor Observed by Solving Circuit Equations

from a Magnetic Frequency Tripler with Series-Connected Reactors

Takuma Sutani and Kazuo Bessho, Members (Kanazawa Institute of Technology)

\begin{abstract}
In order to elucidate nonperiodic oscillations of a six-dimensional magnetic frequency tripler with series-connected reactors, we execute computer simulations by using the fourth-order Runge-Kutta method, and depict bifurcation diagrams with stroboscopic solutions every $2 \pi$ rad. In a bifurcation diagram we have found a period-doubling bifurcation, and also detected a chaotic attractor of a Poincaré map in a region after the period-doubling bifurcation. This paper describes a circuit for the simulations, an equation of states, a bifurcation diagram, a period-doubling bifurcation in the bifurcation diagram, a chaotic attractor, and time series for the chaotic attractor.
\end{abstract}

キーワード : 周波数三倍器, 分岐図, 周期倍加分岐, カオスアトラクタ, 時系列

\section{1.まえがき}

カオスの研究は, 地球物理学者ローレンツより始まり, 上田による「上田アトラクタ」とメイのロジスティック方 程式におけるカオス的構造の研究を経て，1975年リーと ヨークによる論文「三周期はカオスを意味する」によって

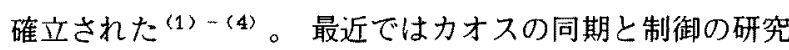
が報告されると共に，電気工学の分野において田所らは三 相非線形回路についてカオス力学的観点による研究を報告 している(5)。なお，対象回路の次元数についてはNavierStokes方程式に関する五次元システムの研究も報告されて いる(6)。しかし, 電気, 磁気回路については三次元シス テムが最大である。

筆者らは，磁気式周波数三倍器の一方式である直列接 続リアクトル回路を用いた周波数三倍器について良好な周 波数三倍特性と定量的な数値解析結果を報告すると共に， フィルタ回路定数不適合による分数調波振動について報告 した ${ }^{(7)}$-(9)。この系の不安定領域における非周期振動に は多くの高調波と分数調波を含み，まさに力オス的挙動で あり，その理論的解明が新たな課題となった。

本研究は，六次元システムとしての単相入力形直列接続 リアクトル回路を用いた周波数三倍器について, 高次元シ ステムに打けるカオス発生機構の解明を目的とし, 回路方 程式を状態方程式の形で求め。これを数值実験する。数値
実験では, 最初に解の挙動に鋭敏な係数の存在を検証し, その係数をパラメータとした分岐図を求める。この結果， 六次元システムにおいて「カオスへの道笳」としての周期 倍加分岐の存在を新たに見いだした。更に，周期倍加分畦 後の領域におけるポアンカレ写像を求めるとカオスアトラ クタを得ることができ, 本システムに拈いても周期倍加分 岐からカオスに至る道筋の存在を立証することができた。

本論文は, 数值実験対象回路, 状態方程式, 数值実験法, 亚びに分岐図について述べる。更に，分岐図のカオス領域 におけるポアンカレ写像上のカオスアトラクタ, 時系列, および㛟討としての累積打切り誤差について述べてある。

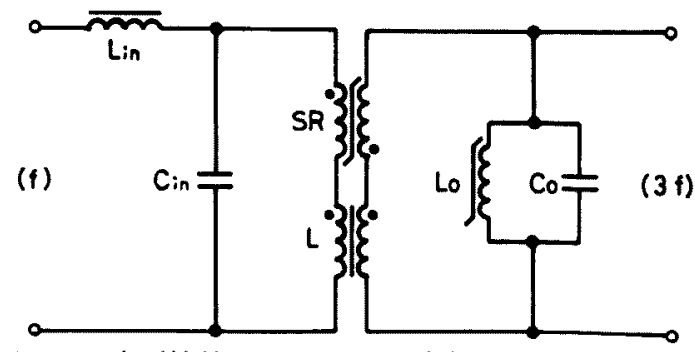

図 1 直列接続リアクトル回路を用いた周波数三 倍器回路

Fig. 1. Circuit diagram of a magnetic frequency tripler with series-connected reactors. 


\section{2. 状態方程式}

図1は直列接続りアクトル回路を用いた周波数三倍器回 路を示す。四において，線形りアクトルL $\mathrm{C}_{1 \mathrm{n}}$ は入力側つィルタ回路である。周波数三倍部は一次側 では同極性に，二次側では逆極性に值列接続された飽和り アクトルSRと線形リアクトルLにて構成されている。周波 数三倍原理は次のとおりである。SRの磁束 $\phi_{1}$ 恃飽和によ り基本周波数と三倍周波数成分を含み，Lの磁束 $\phi_{2}$ は基 本周波数成分のみを含む。これらを二次側で逆極性直列接 統することにより三倍周波数磁束を発生させる訳である。 出力側には, 飽和リアクトルL。とコンデンサC。による三 倍周波数並列共振回路が接続されている。

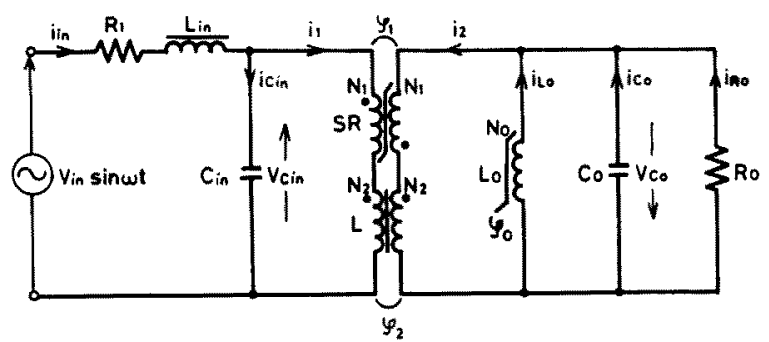

図2 等価回路

Fig. 2. Equivalent circuit of the tripler.

数值実験では，一次側に各リアクトルの銅損分 $\mathrm{R}_{1}$ ，二 次側に負荷抵抗R。を择入した図 2 で示す等価回路を考察 の対象とする。なお，鉄損分は R。に含めるとし，二次側 の銅損分 $\mathrm{R}_{2}$ は $\mathrm{R}$ 。に比較して無視できるものと仮定する。 等価回路に記載の回路定数と変数を用いて回路方程式を求 めると次式を得る(10)。

$$
\begin{aligned}
& R_{1} i_{1 n}+L_{1 n} \frac{d i_{1 n}}{d t}+v_{C 1 n}=v_{1 n} \sin \omega t \\
& i_{1 n}=C_{1 n} \frac{d v_{C 1 n}}{d t}+i_{1} \\
& v_{C 1 n}=N_{1} \frac{d \phi_{1}}{d t}+N_{2} \frac{d \phi_{2}}{d t} \\
& v_{C_{0}}=N_{1} \frac{d \phi_{1}}{d t}-N_{2} \frac{d \phi_{2}}{d t} \\
& v_{C_{0}}=N_{0} \frac{d \phi_{0}}{d t} \\
& i_{2}=i_{L_{0}}+C_{0} \frac{d v_{C_{0}}}{d t}+\frac{v_{C_{0}}}{R_{0}}
\end{aligned}
$$$$
\text { ここで, } N_{1}, N_{2} \text { : 各リアクトルSR, Lの一次と二次 }
$$$$
\text { の巻数, } N_{\circ}: L_{\circ} \text { の巻数, } \phi_{1}, \phi_{2}, \phi_{\circ}: \text { 各リアク }
$$
トルSR, L, L。の磁束鎖交数

電流，電王，磁束を無次元化するため次式と置く。 $\left.\begin{array}{l}i_{1 n}=I_{n} u_{1}, v_{c i n}=V_{n} v_{1}, \phi_{1}=\Phi_{n} p_{1} \\ i_{1}=I_{n} u_{2}, \phi_{2}=\Phi_{n} p_{2}, v_{c 0}=V_{n} v_{2} \\ \phi_{0}=\Phi_{n} p_{3}, i_{2}=I_{n} u_{3}, i_{L 0}=I_{n} u_{4}\end{array}\right\} \cdots(2)$
ただし， $u_{1}, u_{2}, u_{3}, u_{4}, v_{1}, v_{2}, p_{1}, p_{2}, p_{3}$ は無次元量である。 $\omega t=\tau$ と置き、(2)式を(1)式に代入すると次式を得る。

$$
\left.\begin{array}{rl}
\frac{d u_{1}}{d \tau}= & -\frac{R_{1}}{\omega L_{1 n}} u_{1}-\frac{V_{n}}{\omega L_{1 n} I_{n}} v_{1} \\
& +\frac{V_{1 n}}{\omega L_{1 n} I_{n}} \sin \tau \\
\frac{d v_{1}}{d \tau}= & \frac{I_{n}}{\omega C_{1 n} V_{n}} u_{1}-\frac{I_{n}}{\omega C_{1 n} V_{n}} u_{2} \\
\frac{d p_{1}}{d \tau}= & \frac{V_{n}}{2 \omega N_{1} \Phi_{n}}\left(v_{1}+v_{2}\right) \\
\frac{d p_{2}}{d \tau}= & \frac{V_{n}}{2 \omega N_{2} \Phi_{n}}\left(v_{1}-v_{2}\right) \\
\frac{d p_{3}}{d \tau}= & \frac{V_{n}}{\omega N_{0} \Phi_{n}} v_{2} \\
\frac{d v_{2}}{d \tau}= & \frac{I_{n}}{\omega C_{0} V_{n}} u_{3}-\frac{I_{n}}{\omega C_{0} V_{n}} u_{4}-\frac{1}{\omega C_{0} R_{0}} v_{2}
\end{array}\right\}
$$

飽和リアクトルSR, L。の磁化特性を三次多項式近似，線 形リアクトルLの磁化特性を一次近似，すなわち次式と置 $<。$

$$
\left.\begin{array}{rl}
u_{2}-u_{3} & =\alpha p_{1}+\beta^{\prime} p_{1}^{3} \\
u_{2}+u_{3} & =\alpha " p_{2} \\
u_{4} & =\alpha " p_{3}+\beta^{\prime \prime} p_{3}{ }^{3}
\end{array}\right\}
$$

(4)式を(3)式に代入し， $u_{1}=x_{1}, v_{1}=x_{2}, p_{1}=x_{3}, p_{2}$ $=x_{4}, p_{3}=x_{5}, v_{2}=x_{6}$ と置くと, 次式の六次元状態方程式 を得る。

$$
\begin{aligned}
& \frac{d x_{1}}{d \tau}=-k_{1} x_{1}-k_{2} x_{2}+f \sin \tau \\
& \frac{d x_{2}}{d \tau}=k_{3} x_{1}-\alpha_{11} x_{3}-\beta_{11} x_{3}{ }^{3}-\alpha_{21} x_{4} \\
& \frac{d x_{3}}{d \tau}=k_{4}\left(x_{2}+x_{6}\right) \\
& \frac{d x_{4}}{d \tau}=k_{5}\left(x_{2}-x_{6}\right) \\
& \frac{d x_{5}}{d \tau}=k_{6} x_{6} \\
& \frac{d x_{6}}{d \tau}=\alpha_{20} x_{4}-\alpha_{10} x_{3}-\beta_{10 x_{3}}{ }^{3} \\
& -\alpha_{00} X_{5}-\beta_{00} X_{5}^{3}-k_{7} x_{6} \\
& \text { ここで， } \\
& f=\frac{V_{1 n}}{\omega L_{\text {in }} I_{n}}, \quad k_{1}=\frac{R_{1}}{\omega L_{1 n}}, \quad k_{2}=\frac{V_{n}}{\omega L_{1 n} I_{n}} \\
& k_{3}=\frac{l_{n}}{\omega C_{1 n} V_{n}}, \quad k_{4}=\frac{V_{n}}{2 \omega N_{1} \Phi_{n}}, \quad k_{5}=\frac{V_{n}}{2 \omega N_{2} \Phi_{n}} \\
& k_{6}=\frac{V_{n}}{\omega N_{0} \Phi_{n}}, \quad k_{7}=\frac{1}{\omega C_{0} R_{0}}, \quad \alpha_{11}=\frac{I_{n} \alpha}{2 \omega C_{1 n} V_{n}} \\
& \beta_{11}=\frac{I_{n} \beta^{\prime}}{2 \omega C_{1 n} V_{n}}, \quad \alpha_{21}=\frac{I_{n} \alpha "}{2 \omega C_{1 n} V_{n}} \\
& \alpha_{20}=\frac{\ln \alpha "}{2 \omega C_{0} V_{n}}, \quad \alpha_{10}=\frac{\operatorname{In} \alpha}{2 \omega C_{0} V_{n}}
\end{aligned}
$$




$$
\begin{aligned}
& \beta_{10}=\frac{I_{n} \beta^{\prime}}{2 \omega C_{0} V_{n}}, \quad \alpha_{00}=\frac{I_{n} \alpha " '}{\omega C_{0} V_{n}} \\
& \beta_{00}=\frac{I_{n} \beta "}{\omega C_{0} V_{n}}
\end{aligned}
$$

\section{3. 数値実験結果}

$\langle 3.1\rangle$ 分岐図数値実験では，四次 の倍精度ルンゲ・クッ夕法を使用し，刻み 幅は 1 周期を 180 等分, すなわち $\triangle \tau$ $=3.4906585 \times 10^{-2}$ にて行い, 繰り返し回

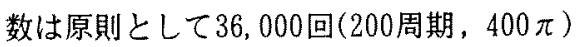
とする。

一般的に，決定論的システム(方程式に よって規定されている系）にはパラメータ を含む。このパラメータを変化させると解 の定性的構造に変化が発生する。この変化 を分岐という(11)。筆者らも，まずカオス

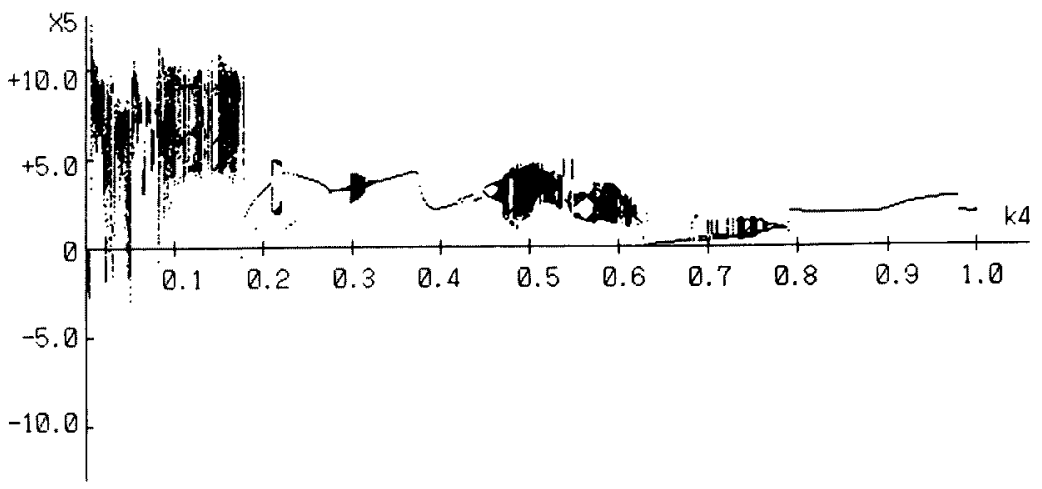

図 3 分岐図

Fig. 3. Bifurcation diagram with $\alpha_{11}=\alpha_{10}=\alpha_{00}=0, \alpha_{21}=5,0 \times 10^{-6}$, $\alpha_{20}=6.0 \times 10^{-6}, \quad \beta_{11}=1.5, \quad \beta_{00}=1.8, \beta_{10}=1.3, f=12.5, \quad k_{1}=0.05, \quad k_{2}$ $=0.011, k_{3}=20, k_{5}=0.2, k_{6}=k_{7}=0.5, x_{10}=1.1, x_{20}=1, x_{30}=5, x_{40}=2, x_{50}=3$, $x_{60}=4$.

領域の存在を検討するため $2 \pi$ 毎の離散的解を用いた分岐 図を求める。離散的解を用いる理由は，1 周期を180等分 した全ての解を用いると帯状の分岐図になり，分岐現象の 観測が不可能になるためである。なお，(5)式は多くの係 数を含み，難解なので非周期振動の発生しやすい領域，す なわち飽和リアクトルの磁化特性における一次の係数を零 $\left(\alpha_{11}=\alpha_{10}=\alpha_{00}=0\right)$ として検討する。

図 3 は $100 \pi \leqq \tau \leqq 400 \pi$ の解和をプロットした分岐図を 示す。困は解の挙動に敏感であり, 飽和リアクトルSRの電 圧 $\mathrm{dp}_{1} / \mathrm{d} \tau$ に対するコンデンサ $\mathrm{C}_{\mathrm{In}_{\mathrm{n}}}$ の電圧 $v_{\mathrm{C}_{\mathrm{in}}}$ とコンデン サC。の電圧 $v_{C}$ の和との比に相当する係数 $k_{4}$ をパラメー夕 とし， $0 \leqq \tau<100 \pi$ 間の過渡的な解を省略してある。なお， 各係数と初期值（初期値の選定は正規化してあるため任意 值）は図に記載した值であり， $\mathrm{k}_{4}$ の刻み幅 $\Delta \mathrm{k}_{4}$ は0.002で ある。困において， $k_{4}=0.1$ 付近はカオス領域であり，そ の後二周期解領域とカオス領域が部分的に存在する。 $\mathrm{k}_{4}$ $=0.45$ では周期倍加分岐らしい遷移を経てカオス領域とな

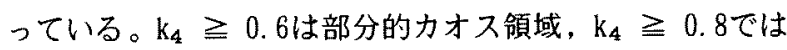
一周期解領域である。

定性的ではあるが，この事実を飽和りアクトルを含む鉄 共振回路と周波数三倍器回路の実験結果と比較すると次の 点で一致している。

（1）飽和リアクトルの端子電圧を低く設定すると不安 定状態になることがある。

（2）出力電圧の跳躍前において二周期解（1／2分数調 波）の発生事例がある。ただし，その発生領域は狭い範囲 である(12)。

（3）跳躍現象後うなりを伴った不安定状態になり，電 圧を更に高めると安定状態に復㷌する。

次に， $k_{4}=0.45$ 付近を扗大すると図 4 を得る。図にお ける $\mathrm{k}_{4}$ の刻み幅 $\triangle \mathrm{k}_{4}$ は 0.00008 あるあ。図は明らかに「力 オスへの道筋」の一形式に相当する周期倍加分岐である。

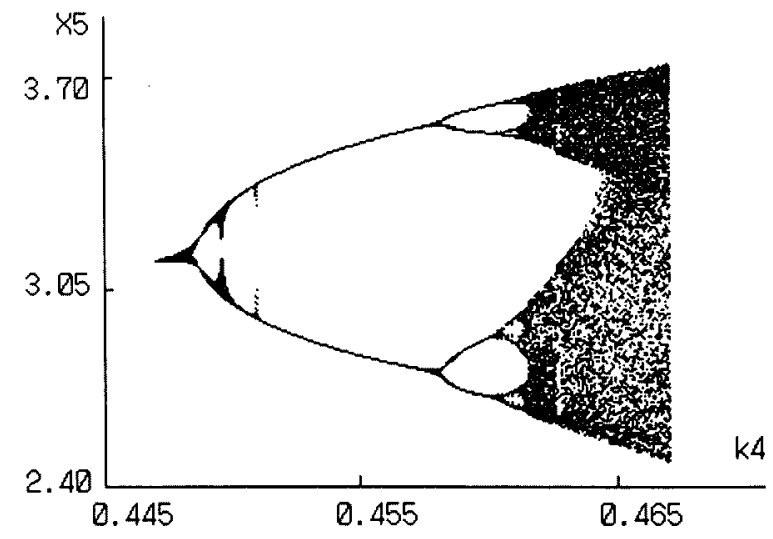

図4 周期倍加分岐

Fig. 4. Period-doubling bifurcation with $\alpha_{11}$ $=\alpha_{10}=\alpha_{00}=0, \alpha_{21}=5.0 \times 10^{-6}, \alpha_{20}=6.0 \times 10^{-6}$, $\beta_{11}=1.5, \beta_{\circ 0}=1.8, \beta_{10}=1.3, \mathrm{f}=12.5, \mathrm{k}_{1}=0.05, \mathrm{k}_{2}$ $=0.011, \mathrm{k}_{3}=20, \mathrm{k}_{5}=0.2, \mathrm{k}_{6}=\mathrm{k}_{7}=0.5, \mathrm{x}_{10}=1.1, \mathrm{x}_{20}=1$, $x_{30}=5, x_{40}=2, x_{50}=3, x_{60}=4$.

一次元ロジスティック方程式において発生する周期倍加分 岐が六次元磁気式周波数三倍器でも発生する原因は，飽和 リアクトルの磁化特性を三次多項式近似したことによると 推定する。ロジスティック方程式における周期倍加分岐の 発生機構は, 変曲点の存在による 1 個の不安定点と安定点 の対の発生が原因と考えられている(13)。磁化特性の三次 多項式近似は変曲点を含み, 上述の条件に合致しやすくな る訳である。

周期倍加分岐においてファイゲンバウムは普遍定数 $\delta を$ 定義し， $\delta=4.6692 \cdots$ であることを報告した ${ }^{(14)}$ 。ファ イゲンバウム定数 $\delta$ は次式で定義される。

$$
\delta=\lim _{n \rightarrow \infty} \delta_{n}=\lim _{n \rightarrow \infty} \frac{\lambda_{n+1}-\lambda_{n}}{\lambda_{n+2}-\lambda_{n+1}}
$$


ここで，入：分岐图における $2,4, \cdots, 2^{\mathrm{n}}$ 周期解へ の分岐時におけるパラメータの值， $\lambda_{n}: 2^{n}$ 周期 解

表 1 ファイゲンバウム定数

Table 1. Feigenbaum's number.

\begin{tabular}{c|c|c}
\hline $\mathrm{n}$ & $\lambda_{\mathrm{n}}$ & $\delta_{\mathrm{n}}$ \\
\hline 1 & 0.44844 & $4.07 \pm 0.17$ \\
2 & 0.45820 & $4.3 \pm 0.8$ \\
3 & 0.46060 & \\
4 & 0.46116 & \\
\hline
\end{tabular}

図4の周期倍加分岐における 2 項目迄の $\delta$ を求めると表 1 の結果になる。モニ夕画面における刻み幅 $\triangle \mathrm{k}_{4}$ の制約と 分岐点の判定困難さのために誤差の多い結果である。しか し，2項目の $\delta_{2}$ は䛊差の範囲内で一致している。なお， ファイゲンバウム定数 $\delta$ 詳細については，モ二夕画面上 の演算ではなく $\triangle \mathrm{k}_{4}$ 倍精度演算の有効数字限界まで小さ くして求める必要があり，これは今後の課題とする。

〈3.2〉 カオスアトラクタ カオスアトラクタの存在 を検討するにはポアンカレ写像を用いる。ポアンカレ写像 とは周期的に駆動される振動系の三次元位相空間 $(x, \dot{x}, t)$ を取扱う方法であり, $\mathrm{tが} \mathrm{T}=2 \pi / \omega_{\mathrm{f}}$ の整数倍になった 時の射影 $(x, \dot{x})$ に相当する。ただし，Tは外力の周期であ 万(15)。

筆者らも，前述の分岐図における周期倍加分岐後の領域

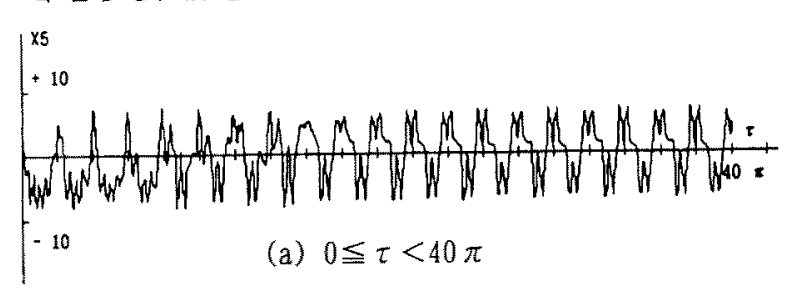
$\underbrace{25}_{-10}=10$
(b) $40 \pi 5 \tau<80 \pi$

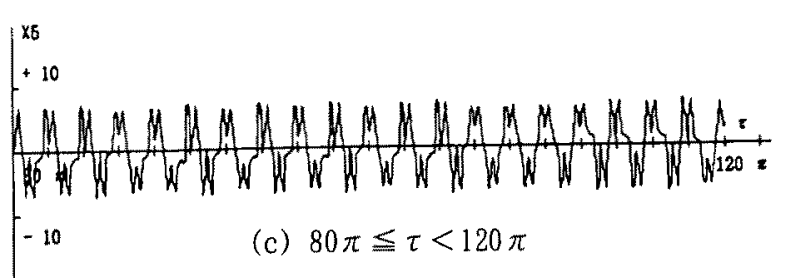

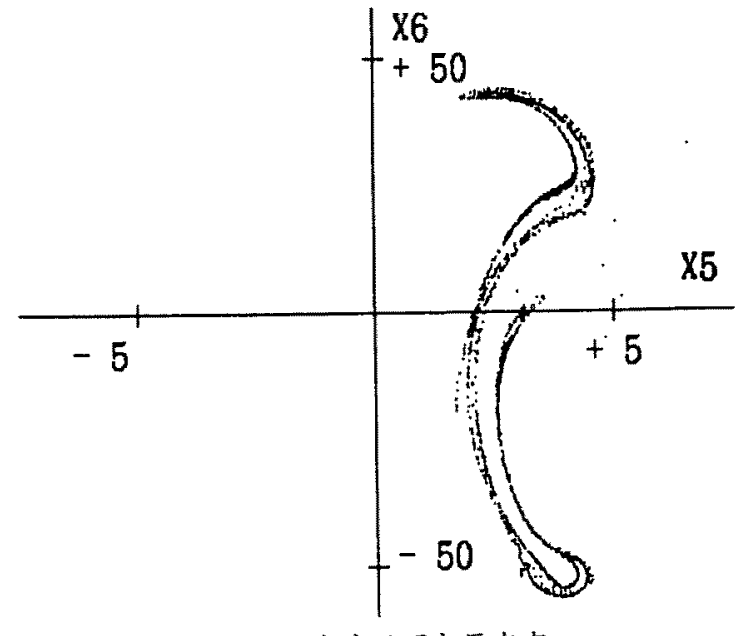

目 5 カオスアトラクタ

Fig. 5. Chaotic attractor with $\alpha_{11}=\alpha_{10}=\alpha_{00}$ $=0, \quad \alpha_{21}=5.0 \times 10^{-6}, \alpha_{20}=6.0 \times 10^{-6}, \quad \beta_{11}=1.5$, $\beta_{00}=1.8, \beta_{10}=1.3, f=12.5, k_{1}=0.05, k_{2}=0.011$, $k_{3}=20, k_{4}=0.5, k_{5}=0.2, k_{6}=k_{7}=0.5, x_{10}=1.1, x_{20}=1$, $x_{30}=5, x_{40}=2, x_{50}=3, x_{60}=4$.

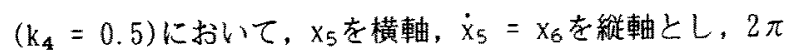
毎のストロボ点を用いたポアンカレ写像を求める。図 5 は, 他の係数を同一とし，2,000周期迄求めたポアンカレ写像 を示す。図は円弧状に解が引き込まれたカオスアトラクタ であり，形状と後述の時系列から判断すると上田アトラク タと異なるカオスアトラクタと考える。
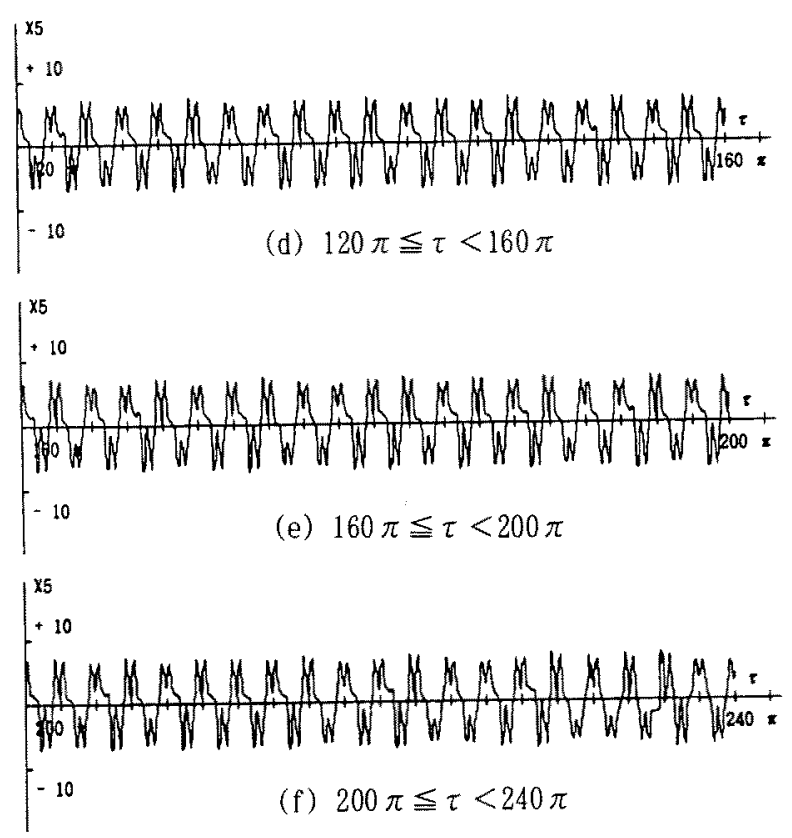

図6 時系列

Fig. 6. Time series untill 120 periods: $\alpha_{11}=\alpha_{10}=\alpha_{00}=0, \alpha_{21}=5.0 \times 10^{-6}, \alpha_{20}=6.0 \times 10^{-6}, \beta_{11}=1.5, \beta_{00}$ $=1.8, \beta_{10}=1.3, f=12.5, k_{1}=0.05, k_{2}=0.011, k_{3}=20, k_{4}=0.5, k_{5}=0.2, k_{6}=k_{7}=0.5, x_{10}=1.1, x_{20}=1, x_{30}=5, x_{40}=2, x_{50}=3$, $\mathrm{X}_{60}=4$. 
しかし，(5)式は次元数こそ六次元であるが，これを非 線形常微分方程式に変換すると二階と三階の非線形連立常 微分方程式となり(8)，部分的にはダフィング方程式に相 当する。従って，図5のカオスアトラクタは上田アトラク 夕と等価であることも予想される。この詳細についてはフ ラクタル次元などを求めて検討しなければならない。本論 文では周期倍加分岐と周期倍加分岐後の領域における力才 スアトラクタの存在を論旨とするため, この検討は今後の 課題とする。

図6は，前述のカオスアトラクタに相当する120周期迄 の時系列を示す。図は，過渡状態を経由した後第三調波の 波高値が定常的に変化すること，および一周期波形におけ る平坦部が微妙に変化（高調波の定常的変化）することを 示している。なおこの時系列は概周期振動ではない。そ

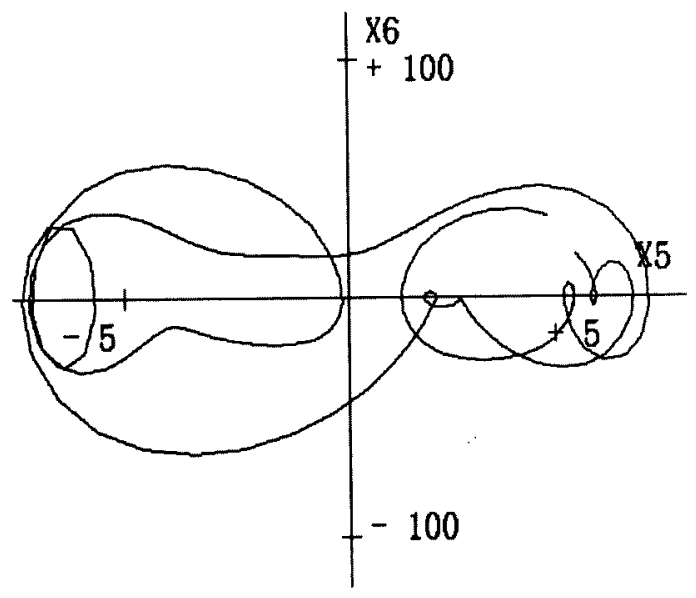

(a) $20 \pi \sim 22 \pi$

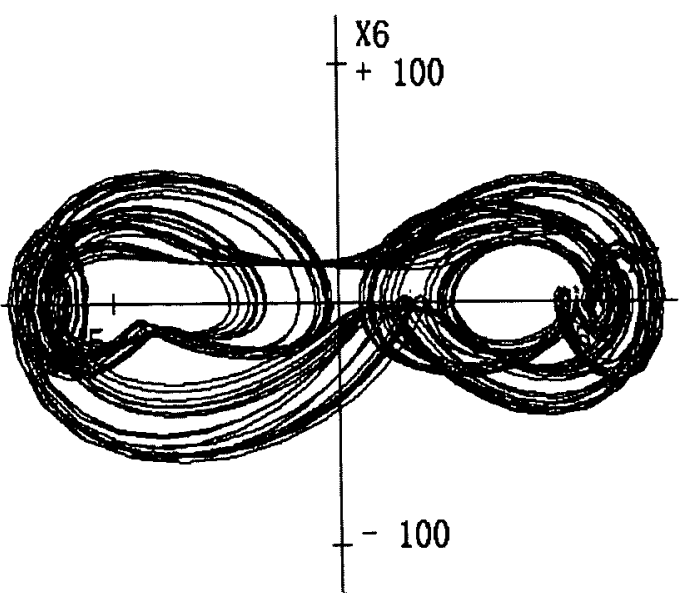

(b) $20 \pi \sim 60 \pi$

図 7 位相軌道

Fig. 7. Phase portrait with $\alpha_{11}=\alpha_{10}=\alpha_{00}=0$, $\alpha_{21}=5.0 \times 10^{-6}, \alpha_{20}=6.0 \times 10^{-6}, \beta_{11}=1.5, \beta_{\circ \circ}$ $=1.8, \beta_{10}=1.3, f=12.5, k_{1}=0.05, k_{2}=0.011, k_{3}=20$, $k_{4}=0.5, k_{5}=0.2, k_{6}=k_{7}=0.5, x_{10}=1.1, x_{20}=1, x_{30}=5$, $x_{40}=2, x_{50}=3, x_{60}=4$.
の理由は，次に述べる位相軌道と本文での記述は省略する が，初期值鋭敏依存性も確認されていることより明らかで ある。また，図の時系列は2,000周期迄求めても同じ傾向 である。図 7 (a)は，時系列における $20 \pi \sim 22 \pi$, 図(b)は $20 \pi \sim 60 \pi$ 間の位相軌道を示す。戝は概周期振動に相当す るトーラスではなく, 高調波を意味する小ループを持つカ オス的軌道である。

\section{4. 検討}

四次のルンゲ・クッタ法における局所打切り誤差は刻み 幅の5乗に比例する ${ }^{(16)}$ 。本数值実験における刻み幅 $\Delta \tau$ を前述の値とすると、局所打切り㺍差 $\varepsilon$ 、は次の値になる。 $\varepsilon_{\mathrm{t}} \propto(\triangle \tau)^{5}=\left(3.4906585 \times 10^{-2}\right)^{5}$

$$
=5.1824702 \times 10^{-8}
$$

丸め愦差は無視できる，および局所打切り誤差は36,000回 (200周期)，360,000回(2,000周期)の繰り返し計算で累積 されると仮定すると, 累積打切り䛊差 $\varepsilon_{\mathrm{at}}{ }^{\prime}, \varepsilon_{\mathrm{at}}$ ” は次の 値になる。

$$
\begin{array}{rl}
\varepsilon_{\mathrm{at}}{ }^{\circ} & 36000 \times 5.1824702 \times 10^{-8} \\
= & 1.8657 \times 10^{-3}(200 \text { 周期 }) \\
\varepsilon_{\mathrm{at}} " \propto \mathrm{c} & 360000 \times 5.1824702 \times 10^{-8} \\
= & 1.8657 \times 10^{-2}(2,000 \text { 周期 })
\end{array}
$$

定量的誤差計算は困難である。しかし, 前述のポアンカ レ写像における $x_{5}, x_{6}$ の值は5〜100であることより, 本数 值実験法は 2,000周期迄計算しても非常に嚍差の小さい方 法といえる。従って, 前述のカオスアトラクタは累積打切 り誤差によるポアンカレ写像上の解の移動により構成され るのではなく，解のわずかな定常的変化によって構成され ることがわかる。

なお, 数値実験においては六次元システムにおける非周 期振動の解明を目的としたため, 電流, 電圧, 磁束を正規 化し，しかも係数を特殊な值，例えば $\alpha_{1 i}=\alpha_{10}=\alpha_{00}$ $=0, \alpha_{21}=5.0 \times 10^{-6}, \alpha_{20}=6.0 \times 10^{-6}$ などを選択し た。この值は, 飽和リアクトルSRの磁化特性は一次の項を 含まず純粋な三次関数的特性であること，および線形りア クトルLのインダクタンスは非常に小さいことを意味する。 すなわち, カオスの発生しやすい領域での定性的な数值実 験結果であり，これらの結果より本周波数三倍器は全領域 にわたってカオス的とは言えない。

従って, 今後は設計論に結び付く定量的な数値実験を行 い, 種々のパラメータとカオス領域との関係を明確にしな ければならない。

\section{5. むすび}

六次元システムとしての直列接続リアクトル回路を用い た周波数三倍器について, 状態方程式を求め, これを四次 の倍精度ルンゲ・クッタ法を用いて数值実験を行った。こ の結果, 飽和リアクトルSRの電圧に対する入力側コンデン

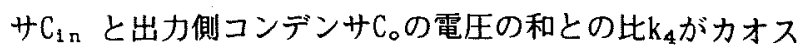
領域への移行を決定する主要因であることが判明した。こ 
のk4 分岐図において，周期倍加分岐の存在を明らかにした。こ れらの結果は, 定性的に飽和リアクトルを含む周波数三倍 器回路の実験結果と一致し, しかも周期倍加分岐後の領域 でカオスアトラクタを得たことより，「カオスへの道筋」 を立証することができた。

カオスアトラクタに相当する時系列については, 第三調 波の波高値の定常的変化によりアトラクタが構成され, 累 積打切り誤差が原因でないこと, および位相軌道により時 系列はカオス応答であることを明らかにした。

今後の課題としては, ファイゲンバウム定数の詳細値を 算出すること,および今回の数值実験で得られたカオスア トラクタのフラクタル次元を求めなければならない。更に, 定量的な数値実験を行い, 本周波数三倍器における非周期 振動の全容を解明すると共に, 非線形磁気回路に内在する カオス的特性の工学的応用とカオスの制御についても検討 したい。

終わりに，本研究に対して貴重な御討論と御助言をいた だいた電気学会マグネティックス研究会と電子情報通信学 会非線形問題研究会の諸氏に深く感謝の意を表します。ま た, 卒業研究として数値実験に従事された平成 5 年度学部 生吉田朱秀, 中村嘉博の諸君に謝意を表します。 (平成6年11月24日受付, 平成7年2月2日再受付)

文献

(1)E. N. Lorenz: "Deterministic Nonperiodic Flow", J. Atmos. Sci., 20, 130-141(1963-3)

(2) 上田睆亮- 赤松則男・林千博：「非線形常微分方程式 の計算機シミュレーションと非周期振動」, 信学論A, 56, 4, 218-225(1973-4)

(3)R. M. May :"Biological Populations with Noneverlapping Generations: Stable Points, Stable Cycles, and Chaos", Science, 186, 645-647(1974-9)

(4)T. Y. Li, J. A. Yorke:"PERIOD THREE IMPLIES CHAOS", Am. Math. Monthly, 82, 985-992(1975-12)

(5) 田所睦雄 - 永田広充・竜田藤男 - 山崎俊洋 : 「三相非 線形回路の異常振動現象の解析」, 電学論D, 110,8, 899-907(1990-8)

(6) V. Franceschini, C. Tebald :"Sequences of Infinite Bifurcations and Turbulence in a Five-Mode Truncation of the Navier-Stokes Equations", J. Stat. Phys., 21, 6, 707-726 (1979)

(7)酢谷玩磨・別所一夫：「三脚鉄心を用いた $\triangle$ 結線形 3 倍周波数莪倍器におけるフィル夕回路定数不適合によ る分数調波振動」, 電気学会マグネティックス研資, MAG-85-179, 27-34(1985-11)

(8)T. Sudani, K. Bessho :"An Analytical Investigation on the Efficiency of a Magnetic Frequency Tripler with Series-Connected Reactors", IEEE Trans. Magn., MAG-23, 4, 1956-1963(1987-7)
(9)酢谷琢磨・別所一夫：「三脚鉄心を用いた $\triangle$ 結線形 3 倍周波数聥倍器の特性と数値解析」, 電学論 D, 108 , 10, 919-926(1988-10)

(10)酢谷环磨・別所一夫：「磁気式周波数三倍器回路方程 式におけるカオスアトラク夕」, 信学技報, NLP93-60, 23-28(1993-11)

(11) J. Guckenheimer, P. Holmes : Nonlinear Oscillations, Dynamical Systems, and Bifurcations of Vector Fields, 117(1986) Springer-Verlag

(12)K. Bessho, F. Matsumura, M. Suzuki:"Some Experiments and Considerations on Behavior of the Power Converter with Bridge-Connected Reactor Circuit", IEEE Trans. Magn., MAG-10, 3, 965-968 (1974-9)

(13) 1. Tsuda: "0n the Abnormality of Period Doubling Bifurcations", Prog. Theor. Phys. , 66, 6, 19852002(1981-12)

(14)M. J. Feigenbaum :"Quantitative Universality for a Class of Nonlinear Transformations", J. Stat. Phys. , 19, 1, 25-52(1978)

(15) J. M. T. Thompson, H. B. Stewart(武者利光監訳, 橋口住久訳) : 非線形力学とカオス， 66-67(1989-3) オーム社

(16) J. M. マコーミク・M. G. サルバドリ（清水留三郎訳） : FORTRANによる数值計算プログラム，91(1974-3) サ イエンス社

酢谷 环磨（正員）1944年10月1日生まれ。67年3月金

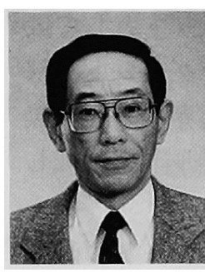
沢大学電気工学科卒業。71年 4 月金沢工業 大学電気工学科助手。75年4月金沢大学大 学院修士課程入学。77年3月同大学院修士 課程修了。79年4月金沢工業高等専門学校 電気工学科講師, 87 年同助教授。94年4月 金沢工業大学工学部工学基礎実技センター 助教授, 現在に至る。主として磁気式周波数迎倍器と非線 形問題の研究に従事。博士(工学), 九州大学。日本応用磁 気学会, 電子情報通信学会会員。

別所一夫（正員）1927年7月1日生まれ。50年3月金沢

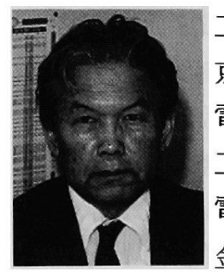
工業専門学校電気工学科卒業。53年4月東 京工業大学電気工学科に勤務，56年10月同 電気工学科助手。68年金沢大学工学部電気 工学科助教授, 71 年 8 月同教授, 82 年 4 月同 電気エネルギー変換実験施設長。93年4月 金沢大学名誉教授, 金沢工業大学非常勤講 師, 現在に至る。主として, 定電圧変圧器, 相数变換器, 周波数聥倍器などの非線形磁気特性を応用した電力変換器 や, 高速度ハイブリッド交流電動機の開発および高速回転 円板形強磁場発生装置, 渦電流形交流強磁場発生装置の研 究に従事。工学博士。日本応用磁気学会, IEEE, 日本ME学 会, 電子情報通信学会会員。 